\title{
The Change of Male Image in Zweig's "Chain Fiction Collection" - Taking family female teacher, letter from an unknown woman and the confusion of feelings as examples
}

Jie Cao"

School of Foreign Languages \& Business, Shenzhen Polytechnic, Shenzhen 518055, and China

This work was supported by the Youth Innovation Project of Shenzhen Polytechnic under grant no.6019310011S.

DOI: $10.36347 /$ sjahss.2020.v08i01.007

| Received: 13.01.2020 | Accepted: 20.01.2020 | Published: 23.01.2020

*Corresponding author: Jie Cao

Abstract

Review Article

Stafan Zweig is an outstanding Austrian novelist. Researchers often focus on the research of female characters in Zweig's writings, and ignore the male characters in his novels. In fact, Zweig's male characters are also distinctive. This article takes the male protagonists in three novels, such as family female teacher, letter from an unknown woman and the confusion of feelings as research objects, analyzes the personalities and similarities of the three main characters, and then explores the roots of the times and social causes.

Keywords: Zweig, Male Image, Change.

Copyright @ 2020: This is an open-access article distributed under the terms of the Creative Commons Attribution license which permits unrestricted use, distribution, and reproduction in any medium for non-commercial use (NonCommercial, or CC-BY-NC) provided the original author and source are credited.

\section{INTRODUCTION About Zweig}

Stefan Zweig (1881-1942) was an Austrian novelist, playwright, and poet who were famous in the literary world from the late 19th century to the mid-20th century. Together with Chekhov in Russia and Maupassant in France, they were the three most outstanding novelists in European literary world of the twentieth century. Zweig was praised by Gorky as "the world's best writers"[1]. From an affluent Jewish family, Zweig studied philosophy and literature in Vienna and Berlin in his youth, then traveled around the world, and became deeply affected by Roman Roland and Sigmund Freud. He wrote poetry, novels, drama, literary theory and biography. Among them, biographical and novel achievements are the most prominent.

\section{Dissemination of works}

Zweig is the most translated German writer in the 20th century after Kafka. It is still one of the most widely read and best-known German writers on all continents. His works have been translated into nearly 60 languages. In China, Zweig is the most published German writer. His masterpieces include the short story Chess Story, letter from an unknown woman, the novel The Scorching Heart, the memoir The World of Yesterday, and the biography The Three Masters and Portrait of a Political Figure. As early as the 1930s,
Zweig's works were introduced to China, and were loved and respected by Chinese readers. In the 1980s, a climax of translation and promotion of Zweig's works appeared. Now, almost all of his works have been translated into Chinese, and many of his masterpieces have several different Chinese translations. Dozens of publishing houses, including the People's Literature Publishing House and Sanlian Bookstore, have competed to publish their works. This formed a striking phenomenon in the history of Chinese foreign literature acceptance.

\section{RESEARCH STATUS \\ Foreign research status}

Although Zweig's works are very popular at home and abroad, he has been treated unfairly in foreign literary critics. His novels are characterized by clever ideas, strange plots, and suspense, because most of his works express lust and secret inner world, so he has been downgraded to "popular writer" by many critics. Throughout the study of Zweig by foreign literary critics, there are mainly the following characteristics and deficiencies: first, his interest in his life is significantly greater than his work; second, his research focuses on Zweig's political attitude in World War II , And his friendship with many famous contemporary writers, such as Freud, founder of the psychoanalytic school. In short, the analysis of the writer himself is clearly more than a systematic study of 
his work. Therefore, analysis of Zweig's works, especially the characters in the works, has become an important research topic.

\section{Current status of domestic research}

The research of Zweig's works is also widely carried out in China. According to the cnki.net search, a total of 660 papers with the theme Stefan Zweig were published. However, previous research scholars often approached from the perspective of narrative skills, psychoanalysis, and film and television adaptations, especially attracted to the most compelling theme in Zweig's novels-the exploration of the psychological mysteries of women. In China's literary research community, research on Zweig's works mainly focuses on the level of female psychoanalysis. This is because Zweig has portrayed the most profound female image through works such as letter from an unknown woman and is therefore known as the male writer who knows the most about women's psychology. Therefore, the existing research focuses on the passionate female images portrayed by Zweig, but the academic results of researching the same colorful male images in his writing are very scarce. After searching, it is found that the number of related papers is zero. It also leaves a huge space for the study of this paper.

\section{MALE CHARACTERS Introduction to Characters}

Characters are the area that has received the most attention and developed most maturely in realistic literary theory. To sum up, it can be divided into three types of character theory: characteristic theory, action theory, and semiotic theory [2].

Character theory that belongs to characteristic theory includes Chatman's concept of "characteristics", Foster's distinction between flat characters and round characters, and Euan's character axis. In the view of action theory characters, the characters at the story level have always been regarded as appendages to the storyline, which is an element of action. The plot occupies the primary position, and the characters are secondary. The role of the characters is only to promote the development of the plot. The semiotic theory treats the character as a semiotic object instead of a sociopsychological object. It distinguishes three types of finger characters, indicator characters, and parallel characters that correspond to finger symbols, indicators, and repeated symbols.

Character creation has always been the direction pursued by traditional aesthetics of the novels. In traditional novels and classic realist novels, there must be a protagonist who constitutes the core of the value of the novel. He has a distinctive appearance, a prominent personality, a clear personality, and is full of drama. And these full-featured characters have obvious social characteristics. They are always in a concrete and personal living environment, and the background of their lives and activities is clearly identifiable. The dramatic conflict between personal passion and social norms constitutes the basic plot of the novel.

Compared with traditional novels, although Zweig's novels also briefly explain the appearance and occupation of the protagonist, he clearly puts the psychological activities of the characters at the center when describing the characters, and everything else is just to better highlight the psychological activities of the characters. The appearance of a character is often closely linked to the description of the person's psychological activity, and in most cases appears as an external manifestation of the psychological activity. Zweig often chooses the parts that best reflect the person's psychological activity for detailed descriptions, such as the person's facial expressions and hands. For example, in the confusion of feelings, the young college student observes the hands of an English professor during class:

"His left hand rests carelessly on the table or at least as if it was there, slightly trembling over his knuckle bone. Slender, a bit too delicate and soft for a man's hand, animatedly depicting invisible characters on the empty template [3]".

This description secretly hides a feminine atmosphere, laying the groundwork for later unlocking the sexual orientation of professors.

\section{Analysis of the male figures in Zweig's masterpiece}

Three masterpieces in Zweig's "Chain Fiction Collection" represent the achievements and style of Zweig's novels, depicting the three stages of children, adulthood and old age respectively.

In 1911, the first book of the "Chain Fiction Collection" was published, entitled "The First Experience", with the subtitle "Four Stories in a Country of Children", including novels such as family female teacher.

Family female teacher tells the tragic story of a young tutor who committed suicide due to unmarried pregnancy. The kind and innocent female teacher was neglected by the host s nephew, a college student, but the fact that she was pregnant made the hostess feel out of shape, so the hostess became angry, and swept her out of the house, driving her to a dead end.

The second book, "Malay Madman" published in 1922, was subtitled "A Collection of Erotic Tales", including novels such as letter from an unknown woman, the work is about a woman, at the last moment, with a lifetime of infatuation, she wrote a long and touching letter, revealing her despairing affection to a famous writer. The novel uses the painful experience of a woman to express the depth and devotion of love. When she was a girl, she fell in love with a stranger 
who was a neighbor, Mr. R. She knows that the playboy of love in this game will not respond to her single love, but still created three opportunities to get close to the writer R, and she raised their son alone. When her son died of the flu and when she was sick and died, she wanted to let the writer know that such a woman had loved him once by the first and the last letter.

The third book, titled "The Chaos of Emotions," published in 1927, explores the inner world of complex middle-aged and elderly people, including novels such as the confusion of feelings.

The first-person narrator, "I", was a young college student who was attracted to the profound knowledge and chic demeanor of a British literature professor in the classroom. Later he lived at the professor's house to help him with some manuscript writing. In the process of contact, he gradually found that the professor's behavior was somewhat abnormal, and the professor's attitude to him was sometimes cold and sometimes enthusiastic. The tenderness and thoughtfulness of the young professor's wife was a kind of spiritual comfort to him. The two could not help but have a one-night stand. The young man talked to the professor in guilt, and confessed his mistake, only to learn the truth. It turned out that the academically accomplished Shakespeare expert was emotionally confused due to his preference for masculinity, and his heart was extremely distressed. He fell in love with the youth, but he tried to suppress his lust. Only by going out to fooling around can he be resolved. The college students remembered this special relationship in their twilight years, and finally dared to admit that they loved the professor.

Judging from the age level of the main male characters in the novel, the undergraduate Alto in the family female teacher is in his youth, the writer $\mathrm{R}$ in letter from an unknown woman is in his adult stage, and the professor in the confusion of feelings belongs to the middle-aged and elderly range.

Judging from the narrative strategies of the three novels, the family female teacher adopts the traditional third-person narrative method. The image of the male protagonist Alto is not much, and it is mainly presented through the perspective of the little sisters, and their focus is mainly focused on in her favorite tutors, Alto's observations are based on the connection with female teachers. The main narrative part of the novel letter from an unknown woman is completed by the first-person narrator at the story level, which tells the story between herself and "you", the writer, mainly through the monologue letter form of the woman. The confusion of feelings uses a flashback, with the third person as the introduction, and the main part mainly uses the first person to tell the past experience of "I" and the professor. However, when the professor tells "me" about his personal life experience, the first person is transformed into a third person. At the same time, from the length of Zweig's description of male characters, the males in the early novels may only belong to the supporting roles, and the males in the later novels can be called the characters of the hero, especially in the confusion of feelings, there are two main characters, "I" and the professor, therefore, Zweig needs to express his male characters through more diverse narrative methods.

Although they are all men, the sexual orientation of college students, writer R, and old professors are different. College students in family female teacher gave birth to the female teacher, and writer $\mathrm{R}$ in letter from an unknown woman also gave birth to their own children. But the confusion of feelings is a gay novel. The professor was emotionally confused due to his preference for masculinity. He fell in love with his students, but tried to suppress his passion. The first-person narrator "I", a student, had a one-night stand with the professor's wife, but when he recalled the past, he also admitted that he loved the professor. Compared to family female and letter from an unknown woman, the emotional world shown in the confusion of feelings is undoubtedly more complicated. It can be seen that Zweig's attention to men in the three representative works of "Chain Novels" shows an increasing trend. These male characters are getting fuller and more complex.

\section{The general character of male characters}

Through comparative analysis, I find that there are some commonalities in the main male characters in the three works.

First of all, whether it's a college student in family female teacher, a writer in letter from an unknown woman, or a professor in the confusion of feelings, and the first-person "I" — a college student, At that time, they were all intellectuals, and It is because of the rich knowledge that the female (male) protagonist in the novel admires.

Although it has a higher social status, these male characters have a side of escapism. After hearing that the female teacher was pregnant, Alto in family female teacher explained to her uncle, "the exam is approaching; he should step up to review his homework, which is too much interference. He wants to rent a house outside and live Two months, and come back after the exam"[4]. In the eyes of the little sister, his timid performance is an act of evasion.

In Austria in the late 19th and early 20th centuries, people cautiously avoided sexual problems, believing it to be a cause of instability, contrary to the ethics of the time. Under these circumstances, Zweig's meticulous research and true and vivid depiction of adolescent psychology were undoubtedly a powerful 
critique of the hypocrisy of the bourgeoisie at the time and Austria's education.

The writer in letter from an unknown woman regards love as a passionate game. Although he has had an affair with too many women, he has never really fallen in love. He told every woman who had a spring break with himself that he would never return with the excuse of "going out and traveling." In fact, it is the prelude to evading responsibility and breaking up. "An unknown woman" thinks that the writer will never believe that she will be loyal to the writer-- "this disloyal man." She feels that the writer "this person only likes the carefreeness in love, the ease and ease of playing games. If you suddenly become a father and suddenly be responsible for a destiny, it will definitely feel embarrassing and tricky [5]".

The professor in the confusion of feelings rarely speaks at home, at least with his wife. The wife never dares to enter the studio without special requirements: this shows that she is completely isolated from his spiritual world. He never talks about his plans and work in front of his wife. In the eyes of the students, when the wife walked into the studio, the professor suddenly stopped his passionate sentence, making the students feel that "this is almost insulting and blatant discrimination, not even a little polite coverup." These "escape" actions are actually manifestations of the male protagonist's disloyalty to his love and respect for women.

Zweig eulogizes the pure humanity that completely excludes utilitarianism, so he expresses a noble feeling in his novels, especially in the drama, love degenerates into commodities, marriage degenerates into transactions. In the context of a capitalist money society, this kind of passionate, reckless, selfless and pure love is even more precious, can only arouse the love and sympathy of readers, such as the "unknown woman", who has no regrets in her life. Many feminists believe that Zweig's works are masculine and inferior, and that the female characters in the novel blindly submit to the male-first social order, which is related to the social and historical background of the time. Women in wealthy citizens' families do not go out to work. It is noteworthy that, Zweig's male protagonist has some female personality traits, such as the timid Alto in family female, the passionate writer in letter from an unknown woman, and the confused professor in the confusion of feelings. This includes Zweig's understanding and sympathy for women, as well as the implicit taunts of these male characters.

\section{Tracing the source of the change of male image}

Zweig was hailed as "the hunter of the human soul"[6] by Roman Roland. He spent his whole life exploring the mysteries of human psychological activity. Why he is so passionate about psychoanalysis of characters is because Zweig is deeply influenced by
Freud's psychoanalysis. Freud was one of Zweig's closest friends. Zweig highly admired Freud's subconscious theory, saying that it pointed out the way to enter the human soul and explore the deep psychological path of man. In his autobiography Yesterday's World-A Memory of a European, he mentioned Freud's subconscious primitive desire many times, and he expressed his admiration for Freud's courageous exploration of "the world's hidden sexual impulsive world", which was listed as a restricted area. Under the influence of Freud, Zweig focused on digging the character's subconscious and exploring the character's deep and mysterious inner world. He used Freud's psychoanalysis to analyze the psychological state of the characters, from the outside to the inside, the characters' hearts were cut into pieces and displayed in front of the reader.

As for Freud's theory, Zweig did not accept it indiscriminately. The psychoanalytic method used in his works has also been influenced by many foreign writers of the same period, such as Stendhal's psychological description and Dostoevsky's portrayal of the ill-conditioned psychology of characters. Zweig's psychological description is based on reflecting reality, which is very different from the "flow of consciousness" technique commonly used in modernism. The character of Zweig's character is very logical, and the cause and effect are very clear. The introduction of psychoanalysis makes Zweig's work unique and fascinating. He focused his attention on the events that best represented the character's personality, selected the moments when the plot broke out or turned, and delicately described the character's psychological and personality characteristics. He used psychological analysis to analyze the spirit and mentality of the characters in the special historical environment, and showed that he thought about human destiny and historical process.

At the same time, Zweig lived between the end of the nineteenth century and World War II, having experienced two world wars in his life. This is a period of transition from European capitalism to imperialism. Conflicts between various imperialisms and between various nationalities and classes within imperialist countries have intensified, eventually leading to the rise of revolutionary waves in various countries, known as the "safe world." In Europe, a general crisis broke out, especially a deep spiritual crisis and a crisis of the times in the upper class of the bourgeoisie, which caused the confusion of class concepts and moral standards and made the traditional bourgeois rational kingdom no longer exist. Zweig witnessed the regression of human beings from a high civilization to primitive barbarism. On the other hand, in the time he lived, human beings had achieved unprecedented achievements in science and technology, surpassing the achievements created in the past thousands of years. In this way, a strange phenomenon appeared in this era: both demon-like 
appearance and the performance created by the gods. All this has deeply imprinted Zweig's ideas and creations. He tried his best to dig the corners of the human soul, and constantly explored the meaning of life with his pen.

The key word of the three masterpieces throughout the "Chain Fiction Collection" is "sex". But in Austria in the late 19th and early 20th centuries, people carefully avoided the topic of "sex". Religion, public opinion, government, and school education spared no effort to denigrate and condemn any sexual activity, and especially strictly forbid talking about "sex". It was considered contrary to the ethics of the time. On the other hand, sexual behavior that violates ethical standards has reached an unprecedented peak. Therefore, the pregnant female tutor was dismissed by the host and scolded, "It's shameless for such a person to want to be a teacher to educate other girls"[7]. The "culprit" Alto does not bear any responsibility. The infatuated woman in letter from an unknown woman hesitates to betray herself and rejects many people's proposals, just to be free when the writer summons herself. The writer only regards love as a game. When he finally read the letter, he couldn't put together the image of this woman who had been obsessed with his life forever. Through these two male figures, the hypocrisy of the bourgeoisie was fully exposed, and Zweig's whipping of the ugly society was expressed. The theme of "homosexuality" in the confusion of feelings was of earth-shattering significance in the contemporary era. The professor was tormented because of his unique sexual orientation, and "I" did not dare to admit that he loved the professor until his twilight years. Zweig expressed his sympathetic understanding of homosexuals and his critique of worldly customs by depicting the psychological world of the two. In summary, Zweig used the "sex" main line to portray more and more prominent male characters, and they were more profound one by one, thus fully exposing their hatred and pitifulness, and then showing his negative attitude towards the social atmosphere at that time.

\section{CONCLUSIONS}

According to Zweig, the belief in the rise of capitalism to resolve all contradictions and conflicts was an illusion. Coupled with the profound pain of life he felt as a result of wandering, it became Zweig's key to open people's inner world. Regarding some ugly social phenomena, Zweig did not make too many positive descriptions, but only devoted himself to the inner world of the characters. On the one hand, he relentlessly condemned this; on the other hand, he was trying to find these morally degenerate Social roots.

Zweig deeply felt the tremendous suffering and misfortune suffered by women in the society, marriage, and family relationships under the capitalist system. The situation of women being sheltered, oppressed, disrespected and insultable has inspired Zweig to think deeply about women's issues. Through the depiction of male characters, they can contrast the spiritual perfection of female characters and the pain in real life. The author's sincere praise and deep sympathy are filled with humanitarian passion. Zweig is therefore called "the male writer who knows the most about women's psychology"[8], but he deserves to be the best writer who knows the psychology of men.

\section{REFERENCES}

1. Zweig S. "Book for three", Hunan: Hunan People's publishing House.1980; 189-211.

2. Han YC. "Zweig Selected Novels", Jiangxi: Jiangxi Education Press.2016; 101-523.

3. Zhang Y. "A Study of Zweig's Short Stories", Beijing: People's Literature Publishing House. 57, 2012.

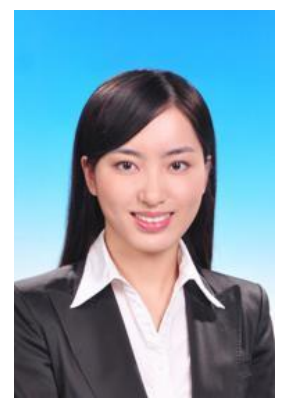

Jie Cao received the MA.degree from Renmin University, in 2013. She is currently a lecturer of Shenzhen Polytechnic. Her research interest mainly focuses on german literature. 